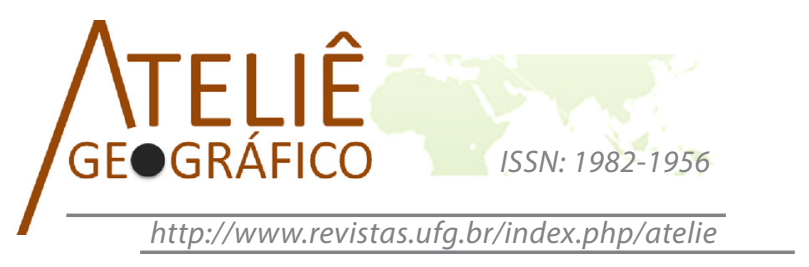

\title{
Inventário e Avaliação do Patrimônio Geológico do Parque Nacional de Jericoacoara, Ceará, Brasil
}

\author{
Inventory and Geoheritage Evaluation in Jericoacoara \\ National Park, Ceará, Brazil
}

\section{Inventaire et Evaluation de l'Héritage Géologique dans le Park National de Jericoacoara, Ceará, Brésil}

\author{
Suedio Alves Meira \\ Universidade Federal do Ceará \\ suediomeira@gmail.com \\ Jader Onofre de Morais \\ Universidade Estadual do Ceará \\ jaderonofre@gmail.com
}

\begin{abstract}
Resumo
Geodiversidade, Patrimônio Geológico e Geoconservação são campos recentes e promissores em meio às Ciências da Terra devido seu caráter ambientalista. $\mathrm{O}$ presente trabalho aborda essas temáticas tendo como objetivo realizar o inventário e a avaliação, segundo o caráter científico e turístico, do patrimônio geológico do Parque Nacional de Jericoacoara, Ceará, Brasil. Para o inventário, utilizouse os métodos Ad Hoc e o de Seleção por Características Superlativas. Foram inventariados sete geossítios na área do Parque. Por meio da avaliação quantitativa, foi possível delimitar os valores intrínseco, científico, turístico e de gestão dos geossítios, posteriormente, através de ponderação distinguiu-se valores de uso e a relevância de cada local. O Parque Nacional de Jericoacoara apresenta um patrimônio geológico diversificado e passível de utilização em práticas educativas. Cabe então aos órgãos gestores incentivarem medidas geoconservacionistas para a área no intuito de salvaguardar essas feições relevantes para a história geológica regional.
\end{abstract}

Palavras-chave: Geodiversidade, Patrimônio Geológico, Geoconservação. 


\begin{abstract}
Geodiversity, geoheritage and geoconservation are recent and promising fields among Earh Sciences due to its environmentalist character. The present work approaches this theme with the aim to make the inventory and the evalutation of geoheritage in the Jericoacoara National Park, Ceará, Brazil, with the scientific and touristic characters. For the inventory we used the Ad Hoc and Superlative Characteristics Selection methods. Seven geosites were inventored in the Park area. By the means of this quantitative evaluation it was possible to stablish the intrinsic, scientific, touristic and administrative values. Later, by weighing we distinguished use values and the relevance of each place. The Jericoacoara National Park presents a diversified geoheritage with educational potentialities. We note that the administration institutions should be responsible to stimulate geoconservationist measures to the area aiming to protect relevant environmental features for the regional geological history.
\end{abstract}

Keywords: Geodiversity, Geoheritage, Geoconservation

\begin{abstract}
Résumé
Géodiversité, héritage géologique et géoconservation sont des champs recents et prometteurs ente les Sciences de la Terre grace à leurs caractère environmentaliste. Le travail présent traite ses thématiques ayant comme objectif la réalisation de l'inventaire et l'evaluation, selon le character scientifique et touristic, de l'héritage géologique du Park National de Jericoacoara, Ceará, Brésil. Pour l'inventaire nous avons utilisé les méthodes Ad Hoc et Selection de Charactéristiques Superlatives. Sept geosites ont été répertoriés dans le Park. Par le moyen de l'évaluation quantitative nous avons établie les valeurs intrins, scientifique, touristique et de gestion des géosites. Après, à travers une pondération nous avons distingué les valeurs d'utilisation et la relevance de chaque endroit. Le Park National de Jericoacoara presente un héritage géologique diversifié et passible d'utilisation dans des pratiques éducatifs. Il est donc de la responsabilité des organes de gestion stimuler des mesures géoconservationistes pour le park avec l'objectif de sauvegarder les elements environnementaux d'importance pour l'histoire géologique de la région.

Mots-Clefs: Géodiversité, Héritage Géologique, Géoconservation
\end{abstract}

\title{
Introdução
}

O Parque Nacional de Jericoacoara (PNJ) é uma unidade de conservação de proteção integral localizada nos municípios de Jijoca de Jericoacoara e Cruz no litoral Oeste do Ceará (Figura 1). Criada no dia 4 de fevereiro de 2002 o Parque apresente área de 8.816 hectares sendo uma Unidade de Conservação (UC) com elevada visibilidade midiática devido à intensa atividade turística firmada nas últimas três décadas.

A justificativa para a instituição do PNJ é a necessidade de proteção do relevante ecossistema costeiro e marinho. Tal justificativa de caráter biótico é comum em áreas protegidas brasileiras, porém, apesar do conceito de ecossistema compreender a interação entre os seres vivos e o meio físico que os sustentam, os estudos e planos de manejo das UC's brasileiras concentram sua atenção na biodiversidade, senso a geodiversidade subjugada. Um exemplo claro é a constância de planos de manejo com poucas páginas dedicadas à abordagem da geologia, geomorfologia, pedologia, entre outros aspectos 
abióticos e a ausência de explicações da interação entre os elementos da geodiversidade e os aspectos culturais e históricos.

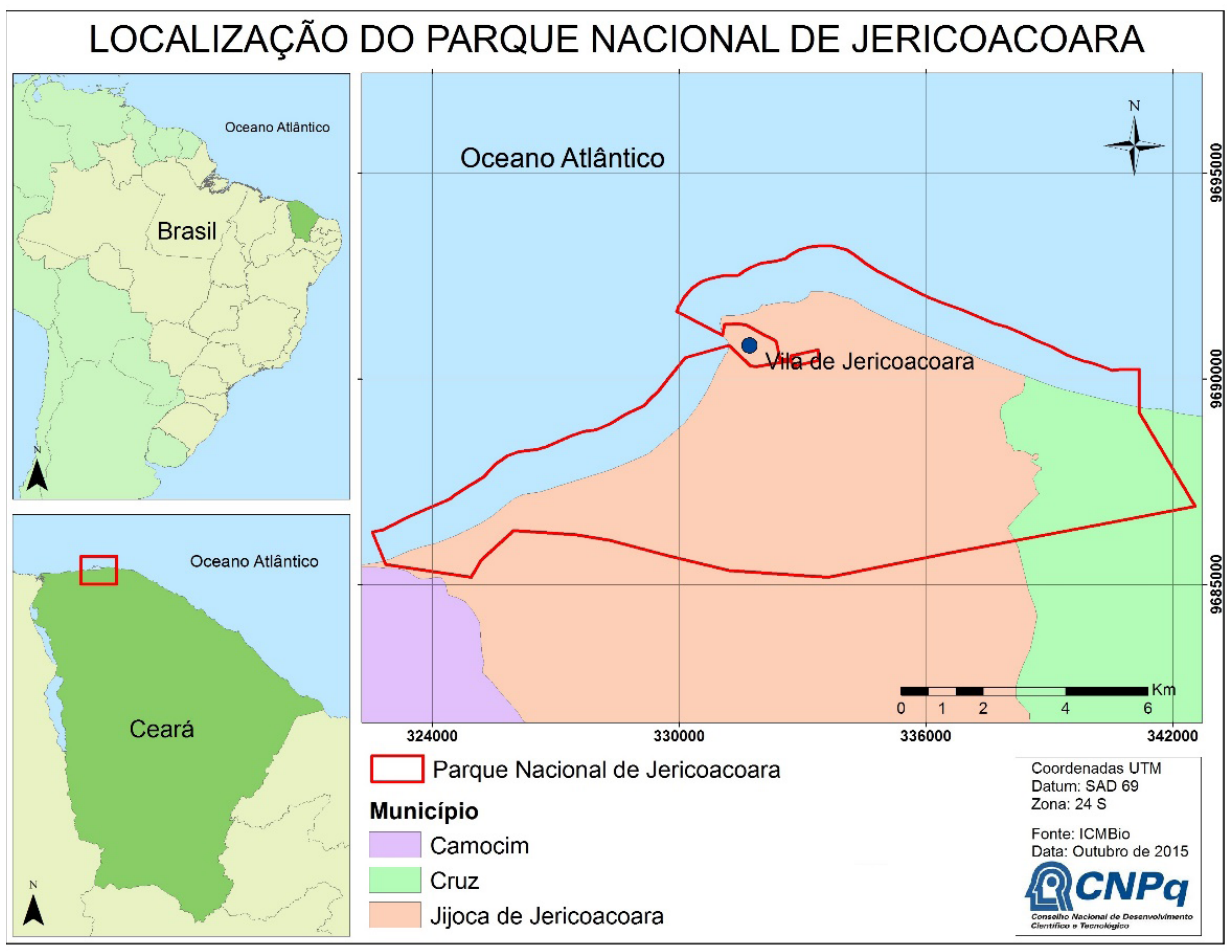

Figura 1. Localização do Parque Nacional de Jericoacoara Fonte: Autoria Própria.

A dificuldade do homem em conceber o meio ambiente enquanto um sistema complexo acaba por gerar uma natureza segmentada. Diante disso, os elementos da biodiversidade apresentam prioridade nos estudos e medidas específicas de proteção, seja por se destacar na paisagem ou dispor de uma escala temporal mais próxima a humana. Porém, esse fato é preocupante já que geodiversidade é a base para toda a forma de vida, o que torna necessário o seu entendimento e a formulação de medidas que visem a sua proteção.

Tendo como preocupação a difusão de conhecimento sobre a componente abiótica da paisagem, emerge na década de 1990 em meio às Ciências da Terra as temáticas da Geodiversidade, do Patrimônio Geológico e da Geoconservação. No âmbito brasileiro os trabalhos iniciaram apenas nos anos 2000 e apesar do esforço de alguns nichos da academia, os estudos e a divulgação ainda é insuficiente, sendo consensual entre os pesquisadores da área de Geociências a necessidade de incentivar pesquisas para que se conheça, promova e proteja o patrimônio geológico nacional. 
Diante o exposto, o presente trabalho objetiva realizar o inventário e a avaliação quantitativa do patrimônio geológico do Parque Nacional de Jericoacoara de acordo suas potencialidades científicas e turísticas. O PNJ apresenta enquanto principais atrativos turísticos elementos de caráter geológico-geomorfológico (campo de dunas, praias, arco marinho, entre outros). Torna-se necessário a discussão sobre o importante patrimônio abiótico e de como esses podem ser utilizados para a difusão de conhecimento relativo às Ciências da Terra visando à consolidação de uma consciência ambiental holística por parte dos visitantes.

\section{Metodologia}

Para realizar o inventário do patrimônio geológico do PNJ, foram combinados os método $A d H o c$ e o de seleção por características superlativas. O método Ad Hoc consiste na "identificação e escolha aleatória de geossítios que são selecionados de maneira isolada e com enfoque local” (PEREIRA, 2010, p. 122), já o de seleção por características superlativas "dispensa pesquisas sistemáticas, contemplando locais de interesse geológico dotados de características superlativas, ignorando o enquadramento ou a contextualização do mesmo" (RIBEIRO et al, 2013, p. 6)

Com a junção dos métodos, realizou-se um inventário que uniu o conhecimento bibliográfico existente da área (salientando locais anteriormente descritos como relevante por outros autores), com os dados e percepções oriundas das saídas de campo.

Foi confeccionada uma ficha de caracterização dos locais de interesse geológico como elemento de auxílio às saídas de campo, sendo esta uma adaptação das propostas por Pereira (2006) e Pinto (2011). A ficha conta com a localização dos locais de interesse geológico, a tipologia do local, descrição geológica sucinta, breve análise de parâmetros de uso e gestão e avaliação preliminar das potencialidades e vulnerabilidades.

A avaliação quantitativa do patrimônio geológico do PNJ seguiu metodologia proposta por Pereira (2010). A escolha deu-se por essa responder a escalas e problemáticas próprias do território nacional, diferentemente de metodologias clássicas da temática que respondem, principalmente, a uma realidade europeia.

A metodologia de Pereira (2010) é composta por 20 parâmetros divididos em quatro categorias de valores, sendo elas: Valor Intrínseco (Vi); Valor Científico (Vci); Valor Turístico (Vtur); e, Valor de Uso e Gestão (Vug). É possível avaliar parâmetros como o Valor de Uso Científico (VUC), Valor de Uso Turístico (VUT), Valor de Conservação (VC) e a Relevância (R) de cada geossítio por meio de ponderações tendo como base as categorias de valor.

\section{Breve abordagem conceitual sobre Geodiversidade e Patrimônio Geológico}

Os estudos em torno da Geodiversidade são recentes se comparados a outros campos das Ciências da Terra, apresentam um caráter ambientalista em seus pressupostos e objetivos fruto de sua formulação mediante contexto histórico da Conferência das Nações Unidas sobre Meio Ambiente e Desenvolvimento de 1992, realizada no Rio de Janeiro (BORBA, 2011). 
O conceito de Geodiversidade atua como um contraponto ao de Biodiversidade, sendo definido enquanto a "variedade de ambientes geológicos, fenômenos e processos ativos que dão origem a paisagens, rochas, minerais, fósseis, solos e outros depósitos superficiais que são suporte para a vida na terra" (BRILHA, 2005, p. 17).

O estudo e a conservação de elementos da geodiversidade são justificados já que esses apresentam uma diversidade de valores associados. $\mathrm{O}$ valor econômico é facilmente concedido no cotidiano à geodiversidade devido aos diversos usos e importância que apresenta para a manutenção da sociedade. Têm-se como exemplo a mineração, a apropriação do solo para ocupação e agricultura, o uso de combustíveis fósseis, entre outros. Porém, o valor econômico é apenas um dos aspectos de relevância. Gray (2004) atribui outros seis grandes categorias de valores para a geodiversidade, sendo elas o valor cultural, estético, funcional, intrínseco, científico e didático.

Os elementos da geodiversidade que apresentam características superlativas devem ser salvaguardados para que as futuras gerações possam usufruir de suas potencialidades. Diante disso, algumas feições da geodiversidade adquirem o status de patrimônio, ou seja, devem ser interpretadas enquanto um bem pertencente à humanidade. Sendo assim, é alçado o conceito de Patrimônio Geológico que é definido sucintamente enquanto "o conjunto de elementos geológicos que se destacam por seu valor científico, cultural ou educativo" (CARCAVILLA et al, 2008, p. 3001, tradução nossa).

Outra terminologia utilizada para designar Patrimônio Geológico é o de Geopatrimônio, a qual surge diante a necessidade de ampliar o sentido restrito do termo "geológico". O conceito de Geopatrimônio é de caráter amplo, estando intimamente relacionado com a definição de sítios geológicos. Porém, é válido salientar que a concepção de Patrimônio Geológico, segundo a corrente teórica predominante, também engloba diversas categorias temáticas (patrimônio geomorfológico, petrográfico, paleontológico, etc.) funcionando enquanto conceito guarda-chuva.

O patrimônio geológico de um determinado local é formado pelo conjunto de geossítios presente. Brilha (2005, p. 52) conceitua geossítio enquanto a ocorrência de "um ou mais elementos da geodiversidade (...), bem delimitado geograficamente e que apresente valor singular do ponto de vista científico, pedagógico, cultural, turístico, ou outro".

Um dos principais objetivos nos estudos das temática da Geodiversidade e doPatrimônio Geológico é a instituição de medidas geoconservacionistas. Cumbe (2007, p. 43) define Geoconservação enquanto o conjunto de "atividades que têm como finalidade a conservação e a gestão do património geológico e dos processos naturais a ele associados". Lima (2008) expõe que uma estratégia de Geoconservação deve seguir algumas etapas para seu sucesso, sendo elas a inventariação, a avaliação quantitativa, a classificação, a conservação, a valorização, a divulgação e o monitoramento do patrimônio geológico. Diante o exposto, o objetivo do presente trabalho entra em concordância com uma estratégia de geoconservação ao realizar o inventário e a avaliação quantitativa de geossítios presentes no PNJ, segundo o caráter científico e turístico. 


\section{Inventário do Patrimônio Geológico do Parque Nacional de Jericoacoara}

Inventariar significa descrever minuciosamente, sendo que nos estudos em Patrimônio Geológico a inventariação constitui a primeira etapa em uma estratégia de geoconservação. Borba et al (2013, p. 276) afirmam que o processo de inventário de geossítios, juntamente com a avalição quali-quantitativa, constitui a 'geoconservação básica', ou seja, os "procedimentos mais fundamentais e que irão embasar subsequentes estratégias de proteção e valorização dos lugares de interesse geológico”.

Seguindo a máxima "conhecer para preservar", o inventário visa o levantamento sistematizado dos geossítios após o reconhecimento prévio da área de estudo, o qual pode ser realizado por levantamento bibliográfico e/ou saídas de campo. Durante essa etapa apenas os locais com características geológicas superlativas são abarcados. Foram inventariados sete geossítios na área do Parque Nacional de Jericoacoara e zonas adjacentes (Figura 2): Duna do Pôr do Sol; Praia da Malhada; Cavernas; Pedra Furada; Pedra do Frade; Dunas Petrificadas; Duna do Funil.

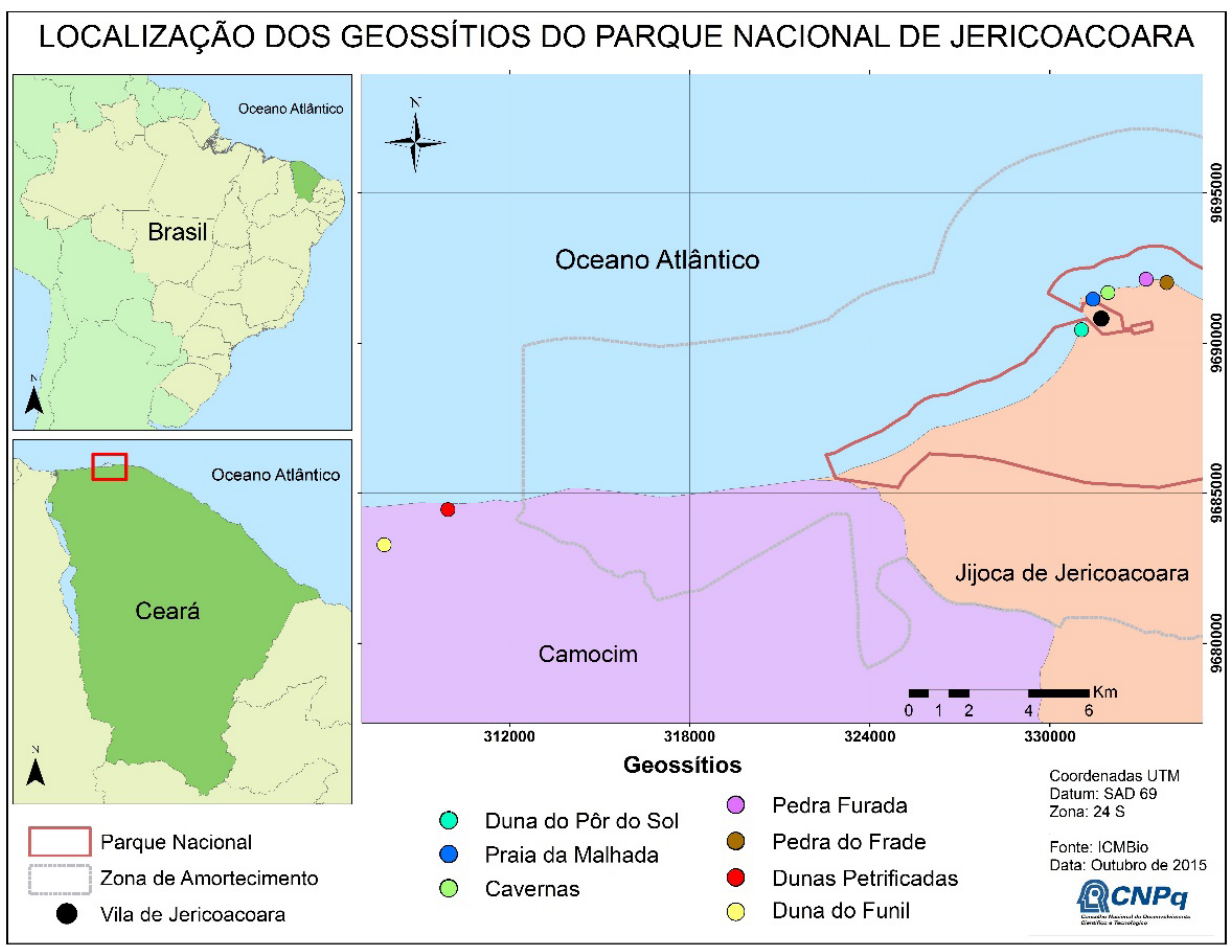

Figura 2. Localização dos geossítios inventariados no Parque Nacional de Jericoacoara Fonte: Adaptado de Meira, 2016, p. 5.

Mesmo com predomínio espacial do campo de dunas no PNJ, os geossítios inventariados abordam diferentes categorias temáticas, apresentando caráter costeiro, 
metamórfico, pseudocárstico, sedimentar e eólico. A área conhecida por Ponta de Jericoacoara, onde ocorre o afloramento de rochas quartzíticas da Formação São Joaquim (caracterizada, geomorfologicamente, pela zona do Serrote e adjacências) e a interação dessa com rochas sedimentares e sedimentos inconsolidados, concentra o maior número de geossítios, sendo cinco no total (Duna do Pôr do Sol, Praia da Malhada, Cavernas, Pedra Furada e Pedra do Frade).

Tendo como base a tipologia de classificação de geossítio proposta por Gutiérrez e Martinéz (2010), é possível assinalar que dos sete locais inventariados cinco constituem geossítios "pontuais" (Duna do Pôr do Sol, Cavernas, Pedra Furada, Pedra do Frade e Duna do Funil), ou seja, locais de pequenas dimensões e caráter isolado onde o elemento da geodiversidade se diferencia do entorno. Os geossítios pontuais apresentam dimensões em torno de um hectare e exibem como característica a elevada vulnerabilidade ambiental devido à dimensão reduzida, mesmo que os elementos do patrimônio geológico não apresentem fragilidade natural (GUTIÉRREZ e MARTINÉZ, 2010).

Os geossítios Praia da Malhada e Dunas Petrificadas são do tipo “área”, o que ocorre quando as feições de interesse se repetem em meio a uma extensão territorial maior. Gutiérrez e Martinéz (2010) expõem que os geossítios áreas apresentam vulnerabilidade reduzida devido à dimensão, porém, no caso do PNJ, o geossítio Dunas Petrificadas é um dos que possui maior vulnerabilidade ambiental devido características intrínseca (ser um depósito eólico).

Os geossítios têm como potencialidade a facilidade de acesso. A Duna do Pôr do Sol e a Praia da Malhada são interligados à Vila de Jericoacoara, facilitando a visitação. Os geossítios Pedra Furada e Pedra do Frade são acessíveis por diversas trilhas de aproximadamente três quilômetros, as quais podem ser realizadas inteiramente á pé pela faixa de praia durante a maré baixa ou pelo Serrote, ou ainda, com auxílio de transporte (charretes ou veículos motorizados) durante uma etapa do percurso sobre o Serrote. Os geossítios Dunas Petrificadas e Duna do Funil integram o roteiro turístico da Vila de Tatajuba no litoral oeste ao PNJ. O único geossítio que apresenta dificuldade de acesso é o Cavernas, o qual é acessível apenas durante a maré baixa e requer caminhada sobre blocos rochosos, porém é passível de visitação por grande parcela do público.

O fato da área ser uma UC do tipo parque limita as atividades econômicas realizadas sobre e no entorno dos geossítios inventariados, sendo assim, favoravél a conservação dos locais. No caso dos geossítios Dunas Petrificadas e Duna do Funil, o mesmo ocorre devido a existência da Área de Proteção Ambiental (APA) de Tatajuba. Porém, a ausência de controle de visitação e do trânsito de veículos, a inexistência de equipamentos de suporte ao turista (como trilhas bem definidas e guiadas) e o incentivo por parte do Governo Federal na instituição de um turismo de Sol e Praia em detrimento de atividades de cunho ecoturísticas constituem elementos que geram vulnerabilidade socioambiental no contexto do PNJ.

Todos os geossítios inventariados são utilizados por práticas turísticas em menor ou maior grau, apresentando diferentes valores (científico, ecológico, cultural e estético) e potencialidades de uso, mediante os diferentes níveis de vulnerabilidade visualizados. Cabe então a caracterização de forma pormenorizada de cada geossítio. 
O geossítio Duna do Pôr do Sol está localizado na continuação oeste da praia principal da Vila de Jericoacoara, sob as coordenadas geográficas $02^{\circ} 48^{\prime} 03,5^{\prime \prime S}$ e $40^{\circ} 31^{\prime} 14,2^{\prime}$ 'W. É um geossítio de relevância cultural por remeter à identidade local e ser apropriado pelo turismo. A localização privilegiada e o fluxo turístico da Duna do Pôr-do-Sol (Figura 3) tornam o local propício para alçar medidas de educação ambiental. Temas relativos à gênese e configuração do campo de dunas de Jericoacoara, a ação do vento e a fragilidade desses ambientes são passíveis de abordagem.

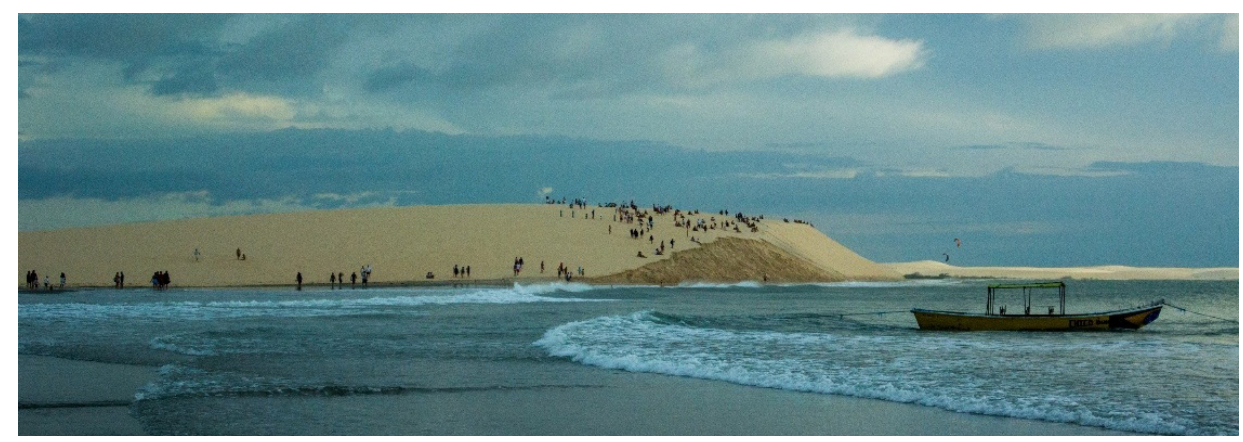

Figura 3. Geossítio Duna do Pôr do Sol

Fonte: Fotografia do Autor (2015).

A Duna do Pôr do Sol é uma duna móvel do tipo barcana, com migração de leste para oeste, em zona de bypassing. Meireles (2011) aponta a formação do campo de dunas de Jericoacoara em períodos de nível de mar mais rebaixado, já que a dinâmica sedimentar atual não tem capacidade de originar dunas dessa dimensão. Com o nível do mar em cotas mais baixas tinha-se uma maior zona de estirâncio, o que permitia o retrabalho dos sedimentos pela ação eólica.

Por meio do estudo da evolução espacial da Duna do Pôr do Sol entre os anos de 1975 e 2010, foi constatada uma diminuição de área em $18.500 \mathrm{~m}^{2}$ devido à migração contínua para a faixa de praia (setor de bypassing, atingindo essa zona a partir da década de 1990), déficit de sedimentos e as mudanças ocasionadas pelo fator antrópico devido à proximidade com a Vila de Jericoacoara (MEIRELES, 2011).

O geossítio Praia da Malhada está conectado à Vila de Jericoacoara em sua porção nordeste, sob as coordenadas 247'26,9'S e 40²1'00,4”W. A noroeste da Praia da Malhada, é possível visualizar blocos isolados de rochas da Formação São Joaquim bastante fraturados e intemperizados, oriundo da ação marinha.

Segundo Julio (2012, p. 39) a Formação São Joaquim é constituída por itabiritos, que "são rochas compostas essencialmente de bandas de quartzo intercaladas com bandas de óxidos de ferro, que variam de milímetros a centímetros de espessura". Outra litologia que compõe a Formação São Joaquim são os quartzitos, que se apresentam com "variável composição mineralógica, incluindo minerais como cianita, silimanita e muscovita com intercalações menores de calcissilicáticas, xistos e metavulcânicas félsicas" (SIQUEIRA, 2011, p. 21). 
Ainda a nordeste, em cota mais elevada, são encontradas lateritas "frutos da oxidação/hidratação dos quartzitos e itabiritos, formando crostas lateríticas com espessura métrica, ricas em manganês e ferro com estrutura botrioidal, fortemente cimentadas e porosas" (JULIO, 2012, p. 45). A formação desses mantos lateríticos é influenciada pelos baixos índices pluviométricos, baixa amplitude térmica anual, altas temperaturas, taxas de evapotranspiração e a posição topográfica elevada.

$\mathrm{Na}$ faixa norte da Praia da Malhada, ocorrem arenitos de praia (beachrocks) (Figura 4a e 4b) e o seu contato com quartzitos da Formação São Joaquim (Figura 4c). Os arenitos de praia se distribuem em outras zonas do PNJ, porém é na Praia da Malhada que são melhor visualizados. Os arenitos de praia são rochas consolidadas "rapidamente pela precipitação de carbonatos na zona de variação do nível d'agua subterrâneo, zona está também relacionada com a subida da maré e com o máximo grau de alternância de clima seco e úmido" (JULIO, 2012, p.63), sendo que em Jericoacoara os mesmos são caracterizados principalmente por conglomerados de rochas quartzíticas.

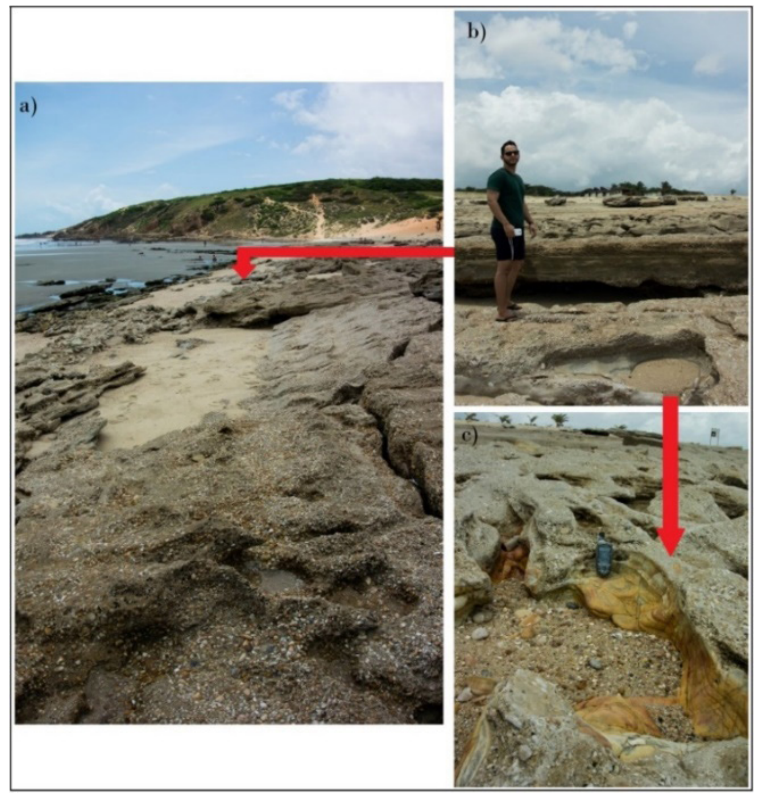

Figura 4. a) Arenitos de Praia. b) Feições erosivas (marmitas). c) Contato litológico Fonte: Fotografias do Autor (2015).

Irion et al (2012, p. 254) abordam a importância dos extensos ciclos de marés - o que permite a permanência dos sedimentos por longo período sem cobertura de lâmina d'agua - e a presença do clima árido na formação dos arenitos de praia presente no Ceará. Os autores ainda apontam a dureza dos arenitos de praia de Jericoacoara os quais “(...) it does not break along the grain borders as one would expect for asediment rock of recent diagenesis, but breaks right through the quartzgrains. This may explain its resistance to erosion and the persistence of its plates" (IRION et al, 2012, p. 254). 
Meireles e Raventos (2002) expõem que os arenitos de praia da planície costeira de Jericoacoara estão dispostos em três níveis topográficos diferentes, sendo um indicador paleoclimático de variação do nível do mar. A deposição dos arenitos ocorreu em ambientes marinhos rasos em eras de transgressão marinha, enquanto que no período de regressivo até atingir a cota atual houve intensa erosão devido ao trabalho das ondas.

Os arenitos de praia, melhor visualizadas durante a maré baixa, estão dispostos em faixas descontínuas de até 20 metros de largura e mergulham suavemente em direção ao mar, apresentam-se em formato de placas (Figura 4a e 4b) devido a estruturas de dissolução marinhas basais. A ação da variação da maré gerou formações erosivas em forma de marmitas na cota mais elevada (Figura 4b). O contato entre os arenitos de praia e os quartzitos da Formação São Joaquim é claro e didático (Figura 4c), sendo possível a sua utilização em explanações sobre diferentes ambientes e processos na formação de rochas, oferecendo assim valor científico e didático elevado.

Meireles e Raventos (2002) salientam que esse contato (Figura 4c) demonstra estabilidade tectônica durante o holoceno, período de formação dos arenitos de praia, já que o quartzito, encontra-se bastante fraturado e o mesmo não ocorre com os arenitos de praia, afirmando que as fraturas foram originadas anteriormente à deposição dos sedimentos.

É possível visualizar pequenas dunas frontais na Praia da Malhada. Os sedimentos que as compõem são oriundos do campo de dunas do interior de Jericoacoara que conseguiram "saltar” a barreira orográfica constituída pelo Serrote. Dos geossítios inventariados, a Praia da Malhada é o que apresenta a maior variedade de elementos da geodiversidade, possibilitando abordagem de temas relativos a rochas metamórficas, sedimentares e diferentes processos de erosão marinha, revelando importante potencial educativo/científico da área. O local se apresenta bastante conservado, sendo pouco susceptível a alteração por atividades antrópicas.

A face norte-nordeste do litoral de Jericoacoara é caracterizada pelo contato abrupto de afloramento de rochas metamórficas da Formação São Joaquim (Serrote) com a linha de costa. Desenvolvem-se feições erosivas oriundas do trabalho marinho em meio à escarpa rochosa. Nesse contexto está inserido o geossítio Cavernas (Figura 5), sendo caracterizado por diferentes pontos entre a Praia da Malhada e a Pedra Furada, onde a principal feição está localizada nas coordenadas $2^{\circ} 47^{\prime} 19,6^{\prime}$ 'S e $40^{\circ} 20^{\prime} 45,2^{\prime \prime} \mathrm{W}$.

As cavernas encontram-se até seis metros acima do nível do mar atual (Figura 5), sendo testemunho de períodos em que esse apresentava cotas mais elevadas. Meireles e Raventos (2002) delimitam cinco estágios de variação do nível do mar que influenciaram a configuração atual da planície costeira de Jericoacoara (duas etapas de transgressão, duas etapas de regressão e processos na cota atual).

As cavernas tiveram a sua origem durante o penúltimo período de transgressão no Pleistoceno "quando o nível do mar atingiu cotas superiores a 6,0m acima da cota de maré máxima atual (evidenciado pelos diferentes níveis de abrasão marinha definidos na plataforma de abrasão)" e a "Ponta de Jericoacoara foi submetida a um complexo processo erosivo, o qual originou arcos e pilares marinhos, bem como níveis escalonados 
de plataforma de abrasão" (MEIRELES e RAVENTOS, 2002, p. 89). Julio et al (2013) salientam que esse período ocorreu há aproximadamente 120.000 anos.

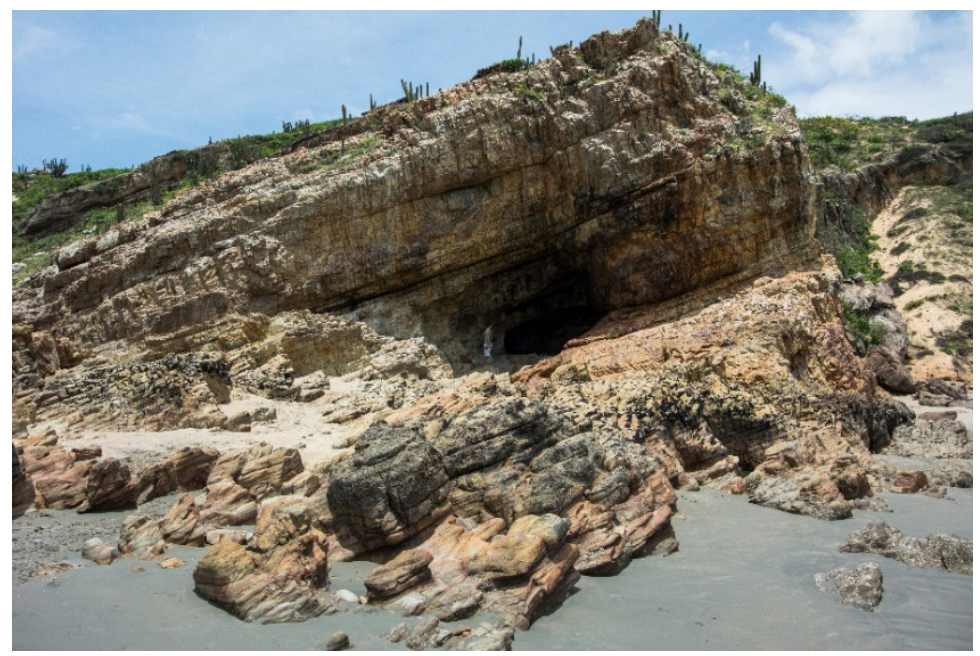

Figura 5. Geossítio Cavernas.

Fonte: Fotografia do Autor (2015).

Os entalhes presentes nos quartzitos entre dois e seis metros acima do nível do mar atual também são salientados por Irion et al (2012) enquanto evidências paleoambientais de nível de mar mais elevado. Segundo os autores esses entalhes, muitos presentes nas entradas das cavernas, são de idade Sangamoniana.

Os quartzitos da Formação São Joaquim apresentam-se bastante fraturados devido às várias fases de "deformações desencadeadas em diferentes níveis crustais e temperaturas, desde o Neoproterozoico até o Cretáceo Inferior" (JULIO, 2012, p. 40). As rochas apresentam uma primeira fase de deformação de caráter dúctil que possibilitou a presença de dobras e uma segunda fase de caráter rúptil, em mais de uma etapa, que resultou nas falhas e no intenso fraturamento.

As fraturas presentes no quartzito contribuíram para o processo de entalhamento das cavernas, já que os processos erosivos e abrasivos das ondas se concentraram nessas zonas de menor resistência. É válido ressaltar que o quartzito é resistente a processos erosivos, mas devido a características locais (presença de fraturas) e intenso trabalho marinho foi possível a evolução das feições erosivas. Sendo assim, as cavernas não apresentam vulnerabilidade diante da utilização antrópica, porém, são encontrados lixo e pichações nas paredes o que acaba por interferir na beleza e na biodiversidade presente, sendo válido a instituição de conscientização ambiental.

O geossítio Pedra Furada (Figura 6), localizado nas coordenadas $2^{\circ} 47^{\prime} 07,2^{\prime \prime} \mathrm{S}$ e 40 $30^{\prime} 05,4^{\prime \prime} \mathrm{W}$, é um arco marinho (arco natural) formado por processos erosivos marinhos. Alguns critérios são necessários para designar uma feição como arco natural, 
sendo eles, o fato de ser formado por rocha, a qual deve estar exposta e rodeada de ar, a abertura deve ter como origem a remoção seletiva da rocha natural e apresentar uma estrutura relativamente intacta na rocha que a circunda (JULIO, 2012).

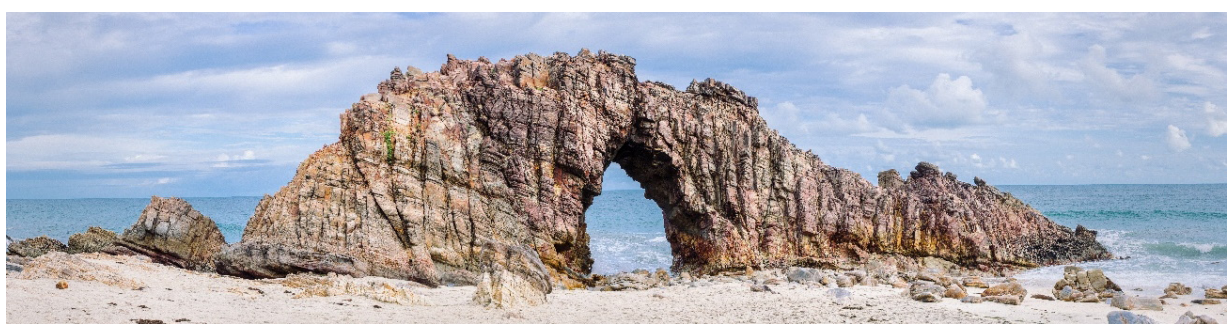

Figura 6. Geossítio Pedra Furada

Foto: Nivando Bezerra (2013).

A Pedra Furada é composta pelo quartzito da Formação São Joaquim que se encontra polido devido à erosão marinha. Julio (2012, p. 59) salienta que esse "processo tem sido incrementado pelos sais presentes na água marinha e no vapor d'água que entram nas fraturas e poros da rocha. Ao cristalizarem-se, os sais formam a desintegração rochosa", o que resulta na superfície rochosa polida e de cantos arredondados.

Ao redor da Pedra Furada é possível visualizar outras feições erosivas, como pequenos pilares marinhos (stacks) e "tocos" marinhos (stumps). As fraturas na rocha são visíveis, sendo passíveis explanações no local sobre a fase rúptil de sua formação.

Julio et al (2013) abordam que a formação da Pedra Furada ocorreu na penúltima transgressão marinha, concomitante à formação das cavernas há aproximadamente 120.000, período em que o mar ficou seis metros acima da cota atual. Meireles e Raventos (2002) complementam que a atual configuração da Pedra Furada é fruto do ultimo evento de regressão do mar, o que teria ocorrido há aproximadamente 5.300 anos.

A Pedra Furada é um dos principais pontos turísticos do PNJ, mas mesmo com o grande contingente de visitantes apresenta-se em bom estado de conservação. Não é encontrada nenhuma pichação ou desgaste na rocha causado por atividade antrópica, bem como lixo no seu entorno. A população local tem um apego com esse monumento natural de forma que os guias orientam os turistas a terem uma atitude consciente.

O geossítio Pedra do Frade está localizado nas coordenadas 247’09,8’S e 40²9'41'W, a aproximadamente um quilômetro da Pedra Furada, sendo possível chegar até ele pela zona de praia. A Pedra do Frade (Figura 7) constitui o melhor exemplar de pilar marinho na Ponta de Jericoacoara. Os pilares marinhos são feições erosivas características na área, porém nenhum apresenta dimensão e facilidade de visualização dos elementos como a Pedra do Frade.

Pilares marinhos são porções mais resistentes de rocha que permanecem como testemunho mesmo após a ação erosiva das ondas. Durante a maré alta, a água atinge a base da Pedra do Frade, sendo essa uma região de maior entalhamento (Figura 7). É possível visualizar fraturas compostas por juntas distensionais e direção principal de orientação no sentido NW-SE, as quais remetem ao período rúptil de formação da rocha. 


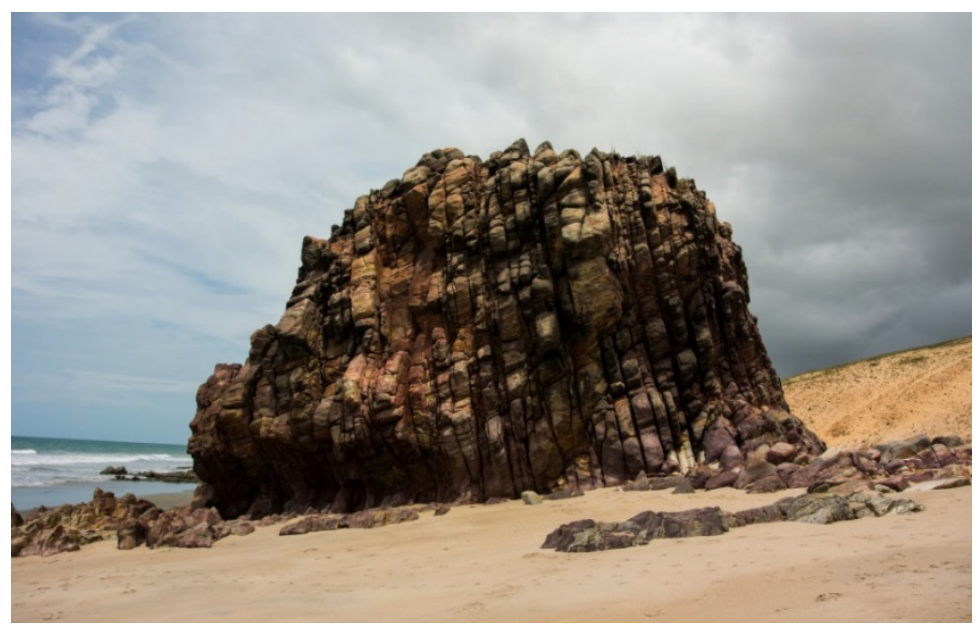

Figura 7. Pilar marinho conhecido como Pedra do Frade Fonte: Fotografia do Autor (2015).

O geossítio Dunas Petrificadas (Figura 8) recebe esse nome já que é assim que o local é conhecido pelos nativos, porém trata-se de um campo de eolianitos (dunas calcificadas), está localizado nas coordenadas $2^{\circ} 51^{\prime} 14,2$ 's e $40^{\circ} 42^{\prime} 36,5^{\prime \prime} \mathrm{W}$. É um geossítio área localizado no município de Camocim, nas proximidades da Vila de Tatajuba, não estando dentro dos limites do Parque Nacional de Jericoacoara, mas à margem da zona de amortecimento, pertencendo à APA de Tatajuba. A inserção desse geossítio pelos autores dá-se pela proximidade e o fato dele estar integrado aos roteiros turísticos do PNJ.

Eolianitos são dunas arenosas cimentadas por carbonato de cálcio cuja ocorrência é documentada em zonas áridas e semiáridas de diversas regiões do mundo, em especial em áreas costeiras com grandes acumulações de areias biogênicas (SANTOS, 2002). Para o Estado do Ceará, os eolianitos foram definidos como

(...) depósitos eólicos cimentados por carbonato de cálcio, segundo um processo que (...) envolveu a dissolução de carbonatos presentes em fragmentos e carapaças biogênicas marinhas, transferidas da plataforma continental adjacente (...), para a zona costeira, durante período de baixo nível do mar e/ ou de mar em descensão; tal contexto teria permitido a migração e posterior estabilização dos depósitos eólicos. Em seguida, ocorreu saturação por água meteórica e cimentação, a partir da precipitação dos carbonatos solubilizados (CARVALHO et al, 2009, p. 122).

Carvalho et al (2009) expõem que os eolianitos ocorrem de forma descontínua em quase toda a costa noroeste do Ceará, entre as localidade de Pecém e Acaraú, apresentando variado grau de litificação, indo do friável ao fortemente litificado. $\mathrm{O}$ geossítio Dunas petrificadas não se encontra no perímetro definido pelos autores, estando localizado mais a noroeste e apresenta grau de litificação baixo (Figura 8a). 


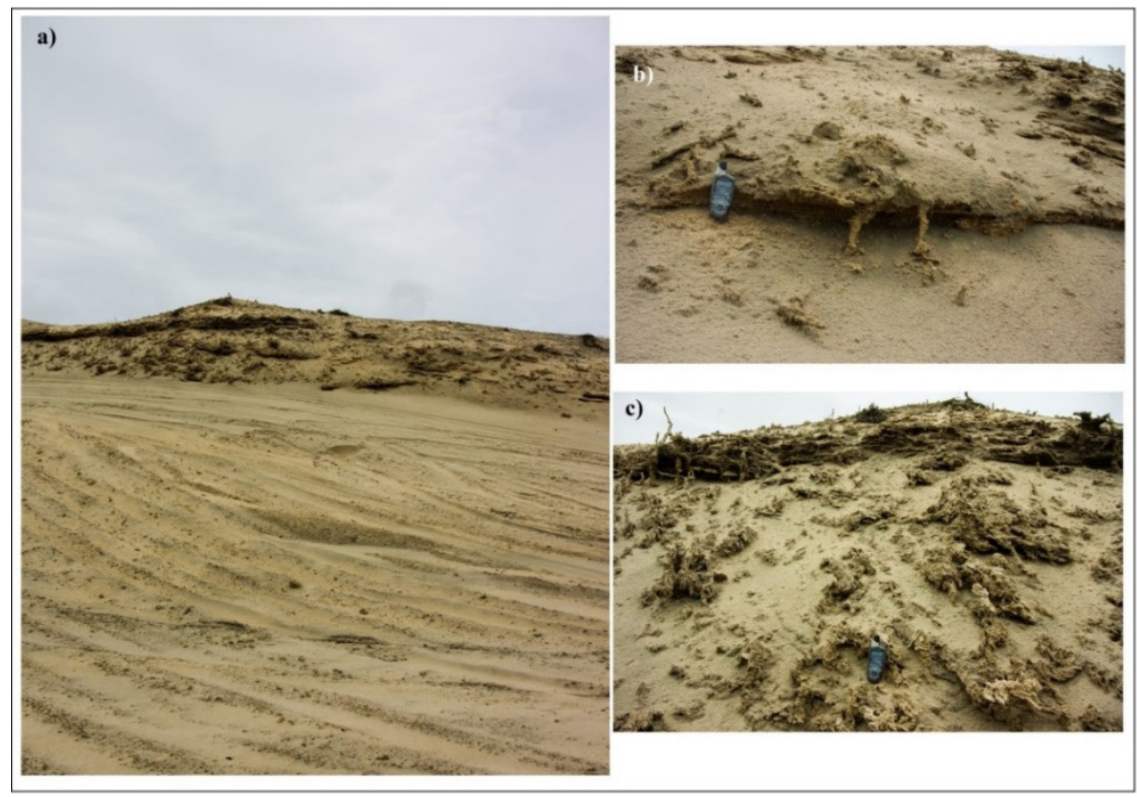

Figura 8. a) Geossítio Dunas Petrificadas. b e c) Raízes litificadas Fonte: Fotografias do Autor (2015).

Os eolianitos apresentam estruturas sedimentares internas caracterizadas principalmente por estratificações plano-paralelas, porém as camadas não são facilmente visualizadas. Ocorre a presença de raízes litificadas (Figuras $8 \mathrm{~b}$ e 8c), fruto da substituição parcial da matéria orgânica por carbonato de cálcio, o que indica que as dunas foram fixadas por vegetação costeira antes do processo de calcificação.

Em meio ao campo de eolianitos, passa a trilha que leva à Duna do Funil e à Lagoa da Torta. A trilha, utilizada por carros, motos e bugues, é bem sinalizada o que diminui o impacto sobre a feição. A vulnerabilidade desse local diante da ação antrópica é elevada, o que gera a necessidade de conscientização de sua relevância.

$\mathrm{O}$ geossítio Duna do Funil também está localizado às margens da zona de amortecimento, pertencendo à APA de Tatajuba, nas coordenadas $2^{\circ} 51^{\prime} 52,1^{\prime \prime} \mathrm{S}$ e 4043'45,3"W. O local constitui um geossítio isolado de caráter eólico/sedimentar (Figura 9). A Duna do Funil é uma duna barcana com a presença de lagoa interdunar na base durante o período chuvoso. Conhecida como a maior duna do PNJ é atrativo nos passeios realizados para oeste da Vila de Jericoacoara.

Do alto da Duna do Funil é possível ter uma vista panorâmica do campo de dunas a oeste do PNJ, da linha de costa, de áreas de planície fluviomarinha com manguezal e da Lagoa da Torta. O local apresenta potencialidade educativa devido à facilidade de visualização dos elementos da geodiversidade e por ser bastante frequentado por turistas, os quais geralmente chegam a esse ponto acompanhados por guias, o que tornaria relevante a capacitação desses para explicar os processos presentes na formação da paisagem. A 
Duna do Funil apresenta alta vulnerabilidade ambiental por ser um elemento bastante mutável, o que torna necessário a instituição de trilhas prioritárias ao tráfego de veículos.

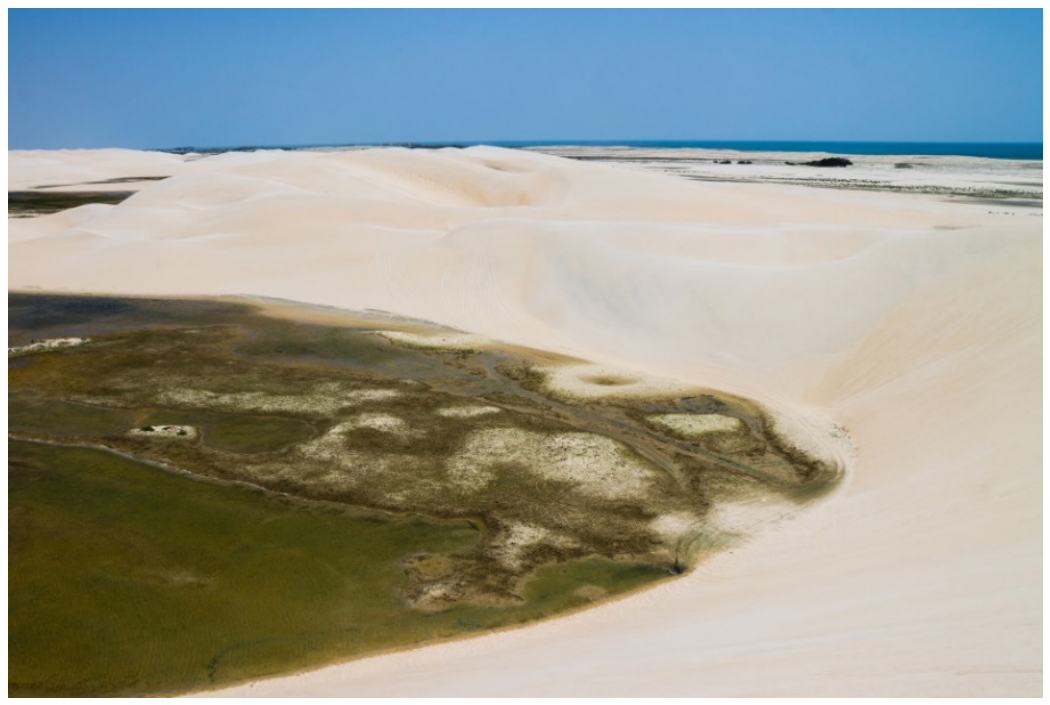

Figura 9. Geossítio Duna do Funil

Fonte: Fotografia do Autor (2015).

\section{Avaliação do Patrimônio Geológico do Parque Nacional de Jericoacoara}

No estudo do patrimônio geológico a etapa de avaliação é realizada após o inventário. Adquire importância por ser através dela que se obtêm uma melhor interpretação dos elementos abióticos, dos seus diversos graus de valores e de quais os geossítios passíveis de instituição de medidas de conservação, valorização e/ou divulgação.

A avaliação pode ser de caráter qualitativo, que realiza a descrição das potencialidades e vulnerabilidades de forma cursiva e sem padronização, ou de caráter quantitativo, que define parâmetros e valores numéricos pelos quais todos os locais de interesse geológico devem ser analisados.

A avaliação quantitativa realizada revelou particularidades do patrimônio geológico do PNJ, como os geossítios prioritários para ações de divulgação e aqueles que apresentam menor relevância científica e turística. Cabe então nesse momento uma descrição dos resultados obtidos.

O Valor Intrínseco, que quantifica parâmetros inerentes ao patrimônio geológico e ao contexto geológico regional em que estão inseridos, apresentou grande variação (3 pontos), com valor mínimo de 0,5 para a Duna do Funil e valor máximo, 3,50 para a Pedra Furada (Quadro 1). O parâmetro abundância/raridade (A-02) foi relevante, pois os geossítios de natureza eólica/sedimetar, caracterizados por dunas, apresentaram 
valores mínimos devido à constância da feição na área de pesquisa. A baixa variedade de elementos da geodiversidade (A-04) em alguns geossítios também contribuiu para o decréscimo do resultado.

Quadro 1. Valor Intrínseco dos Geossítios Inventariados

\begin{tabular}{|c|c|c|c|c|c|c|c|c|c|}
\hline & & 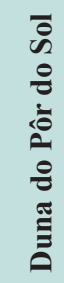 & 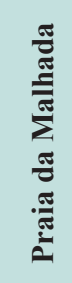 & Uू & 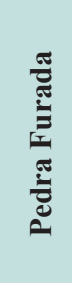 & 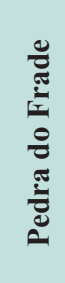 & 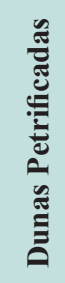 & 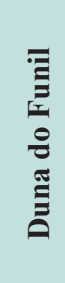 & 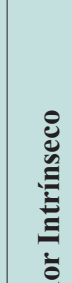 \\
\hline $\mathbf{A}$ & VALOR INTRÍNSECO & & & & & & & & \\
\hline A-01 & $\begin{array}{l}\text { Vulnerabilidade associada a } \\
\text { processos naturais }\end{array}$ & 0 & 2 & 2 & 2 & 2 & 0 & 0 & \\
\hline A-02 & Abundância/Raridade & 0 & 3 & 3 & 4 & 1 & 4 & 0 & \\
\hline A-03 & Integridade & 1 & 4 & 4 & 4 & 4 & 1 & 3 & \\
\hline A- 04 & $\begin{array}{l}\text { Variedade de elementos da } \\
\text { geodiversidade }\end{array}$ & 1 & 3 & 2 & 4 & 2 & 2 & 3 & \\
\hline & Valor Intrínseco & 0,50 & 3,00 & 2,75 & 3,50 & 2,25 & 175 & 150 & 2,18 \\
\hline
\end{tabular}

Fonte: Elaborado pelo autor.

O Valor Científico revela a potencialidade científica do geossítio por meio das interações das diferentes temáticas passíveis de abordagem, bem como se esse já foi alvo de estudos anteriores no âmbito das Ciências da Terra. Esse índice apresentou variação de dois pontos, sendo o menor valor atribuído 1,50 à Duna do Funil e o maior, 3,50, à Pedra Furada (Quadro 2). O parâmetro B-01 foi relevante para o resultado, já que os geossítios localizados na Ponta de Jericoacoara (com exceção da Pedra do Frade) são citados em diferentes estudos (ARRUDA, 2007; MEIRELES, 2011; JULIO, 2012; JULIO et al, 2013), recebendo assim, o valor máximo. No geral, não se alcançou elevada pontuação na diversidade de interesses (B-03), o que revela o caráter eminentemente geológico/geomorfológico dos locais inventariados.

O Valor Turístico (Vtur), que descreve o atual uso turístico do geossítio e as potencialidades desses na implementação de futuras atividades, apresentou pouca variação. O geossítio Duna do Pôr do Sol dispôs do maior valor, 2,60, enquanto as Dunas Petrificadas, o menor atingindo apenas 1,20 (Quadro 3). Apesar dos geossítios apresentarem um elevado apelo cênico, eles não são dotados de estrutura de suporte ao turista, sendo acessível apenas por trilhas (salvo a Duna do Pôr do Sol e a Praia da Malhada que são conectadas à Vila de Jericoacoara), além de não disporem de controle sistemático de visitantes. O conjunto de fatores não permitiu que o Vtur atingisse pontuação elevada, porém são esses mesmos elementos que tornam o turismo no PNJ 
diferenciado. A ideia de contato com a natureza como ela é, do local isolado, das longas caminhadas, do paraíso "natural" é o que atrai os turistas.

Quadro 2. Valor Científico dos Geossítios Inventariados

\begin{tabular}{|c|c|c|c|c|c|c|c|c|c|}
\hline & & 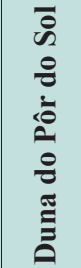 & 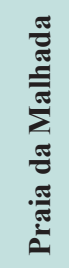 & 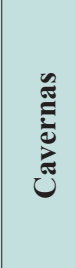 & 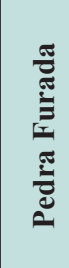 & 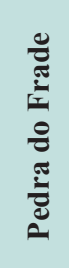 & 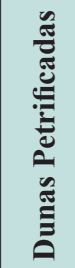 & 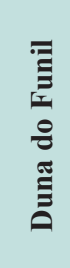 & 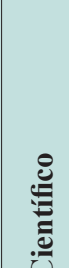 \\
\hline B & VALOR CIENTÍFICO & & & & & & & & 흘 \\
\hline B-01 & $\begin{array}{l}\text { Objeto de referência } \\
\text { bibliográfica }\end{array}$ & 4 & 4 & 4 & 4 & 2 & 2 & 1 & $\frac{1}{2}$ \\
\hline B-02 & $\begin{array}{l}\text { Representatividade dos } \\
\text { materias e dos processos }\end{array}$ & 2 & 4 & 4 & 4 & 2 & 2 & 2 & 莺 \\
\hline B-03 & $\begin{array}{l}\text { Associação com outros } \\
\text { elementos do patrimônio } \\
\text { natural/cultural }\end{array}$ & 0 & 1 & 1 & 2 & 1 & 1 & 1 & \\
\hline B-04 & Relevância didática & 4 & 2 & 2 & 4 & 2 & 2 & 2 & \\
\hline & Valor Intrínseco & 2,50 & 2,75 & 2,75 & 3,50 & 1,75 & 1,75 & 1,50 & 2,36 \\
\hline
\end{tabular}

Fonte: Elaborado pelo autor.

Quadro 3. Valor Turístico dos Geossítios Inventariados

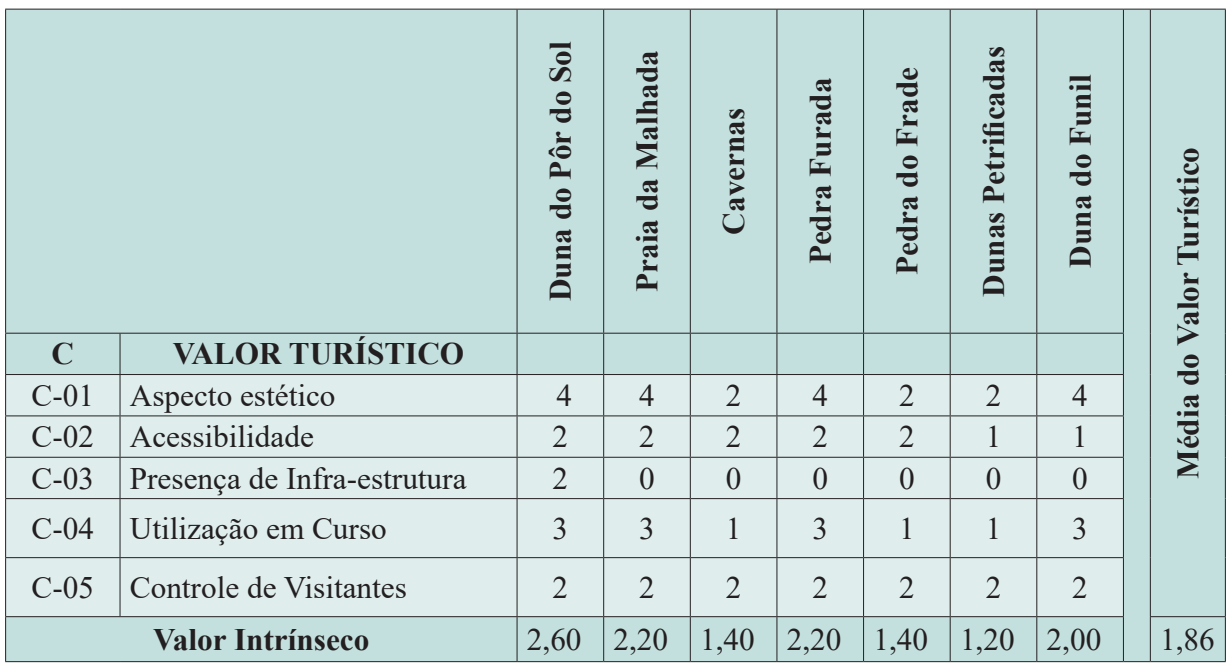

Fonte: Elaborado pelo autor. 
O Valor de Uso/Gestão, que demonstra os impactos sociais vigentes e a viabilidade de utilização futura do geossítio, apresenta particularidades devido aos geossítios estarem presentes em UC's, e num mesmo contexto político e econômico. Dessa forma, todos os locais receberam importâncias iguais em diversos parâmetros (Quadro 4). O valor de Uso/Gestão dos geossítios apresentou pouca alteração, estando todos a menos de 0,5 pontos da média. Apenas os parâmetros que tratam dos aspectos culturais e da vulnerabilidade frente ao uso antrópico (D-01 e D-05) apresentaram variação.

Quadro 4. Valor de Uso/Gestão dos Geossítios Inventariados

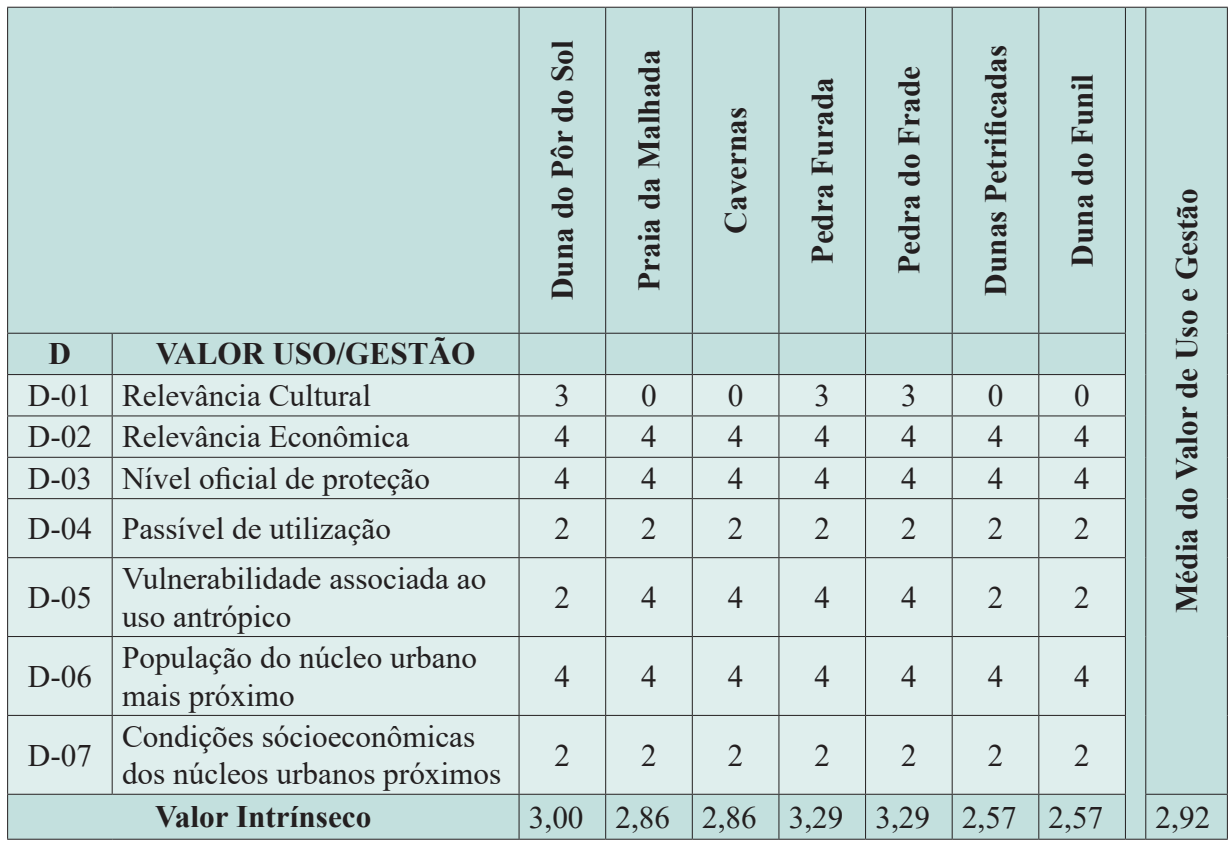

Fonte: Elaborado pelo autor.

Por meio da ponderação dos valores anteriormente descritos, foi possível chegar à definição dos Valores de Uso Científico (VUC), de Uso Turístico (VUT), de Conservação (VUC) e de Relevância (R). Essas informações trazem um contributo prático e aplicável ao planejamento do patrimônio geológico do PNJ. Dois geossítios se destacam apresentando todos os valores finais acima da média da categoria, sendo eles os geossítios Pedra Furada e Praia da Malhada (valores salientados no Quadro 5). Outro geossítio com bom desempenho foi o Cavernas, com pontuação abaixo da média apenas no VUT (Quadro 5). Os geossítios localizados na Ponta de Jericoacoara apresentam as melhores colocações no Ranking de Relevância, demonstrando que a área é prioritária para medidas de valorização e divulgação (Quadro 5). 
O VUC demonstrou que os principais geossítios de aporte a pesquisa no âmbito das Ciências da Terra são Pedra Furada (3,50), Praia da Malhada $(2,85)$ e Cavernas $(2,75)$. Todos estão localizados na Ponta de Jericoacoara sobre rochas metamórficas pertencentes à Formação São Joaquim, sendo que na Praia da Malhada ainda é possível explanar sobre formações sedimentares devido à presença de arenitos de praia. São geossítios que remontam diversos processos erosivos e de abrasão marinha, além de testemunhar diferentes níveis relativos do mar, apresentando assim importância paleoclimática. Em contrapartida, os geossítios caracterizados por dunas apresentam os menores valores, Dunas Petrificadas $(1,75)$, Duna do Funil $(1,70)$ e Duna do Pôr do Sol $(1,50)$. A constância das feições no PNJ e litoral cearense, a baixa diversidade de elementos passíveis de abordagem em conjunto com alta vulnerabilidade mediante o uso são as principais causas para os baixos índices alcançados.

Quadro 5. Valor Síntese dos Valores de Uso e Relevância dos Geossítios Inventariados

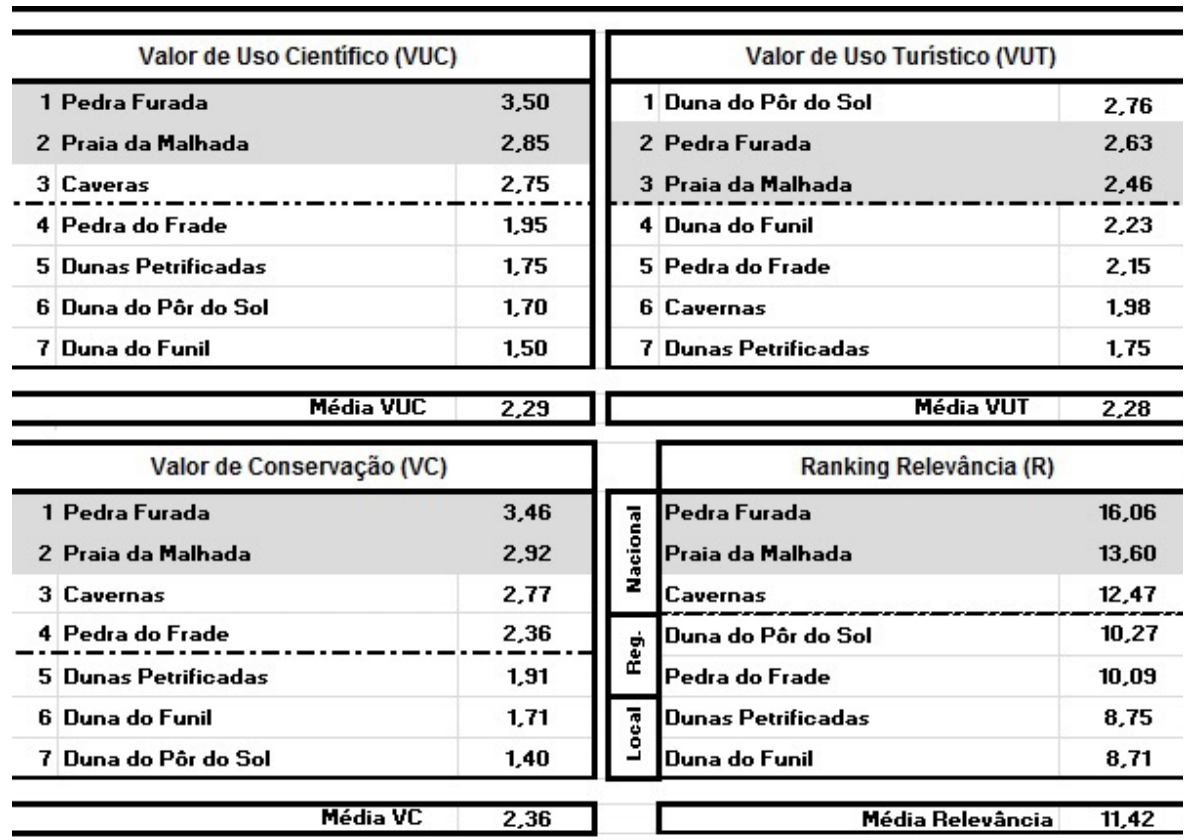

Geossítios com valores acima da média para todas as cateqorias de uso, indicando prioridade de acốes

Fonte: Elaborado pelo autor.

O VUT apresentou pouca variação entre os geossítios. A ausência de infraestrutura de suporte ao turista e as distâncias foram os grandes empecilhos para um melhor resultado. O geossítio Duna do Pôr do Sol devido a proximidade da Vila de Jericoacoara, a lendas e identificação cultural, a elementos de suporte ao turista (mesmo que de forma incipiente através da possibilidade de "subir" a duna à cavalo) apresentou 
o maior valor $(2,73)$, seguido da Pedra Furada $(2,63)$, sendo esses os principais pontos turísticos do PNJ.

Esses dois locais, juntamente com a Praia da Malhada, podem ser amplamente utilizados para práticas de conscientização ambiental em meio aos turistas que frequentam o PNJ devido ao grande número de visitantes e a boa visibilidade dos elementos da geodiversidade. A Duna do Pôr do Sol apesar de não apresentar grande relevância científica, pode ser apropriada mediante as lendas e a mística por trás do pôr do sol que todos os turistas vão assistir quando visitam Jericoacoara.

O VC “expressa a relevância do geossítio para fins de conservação dos elementos da geodiversidade" devendo-se considerar que a "conservação do patrimônio natural deve ser encarada como uma atividade que tenha um impacto social positivo e que, para além disto, tenha em consideração a relevância científica do local" (PEREIRA, 2010 , p. 208). Foi constatada uma elevada variação na área de pesquisa, 2,06 pontos, por haver no PNJ dois grandes grupos de geossítios. O primeiro de características eólicas/ dunares com alta vulnerabilidade ambiental, baixa raridade e valor científico e o segundo caracterizado por geossítios oriundos de processos erosivos sobre rochas metamórficas e/ou sedimentares com menor grau de vulnerabilidade e maior número de elementos associados.

O Ranking de Relevância resultou em geossítios de importância local, regional e nacional. Foram dois geossítios de relevância local: i) Dunas Petrificadas, com valor de 8,75; ii) Duna do Funil, que apresenta o menor valor de relevância com 8,71 pontos. A Duna do Funil produziu o valor mais baixo no parâmetro de Valor de Uso Científico, enquanto as Dunas Petrificadas assume essa posição no Valor de Uso Turístico.

Dois geossítios enquadram-se como de relevância regional: i) Duna do Pôr do Sol, que apesar do baixo valor científico foi o principal expoente da área de pesquisa no Valor de Uso Turístico, atingindo valor 10,27; ii) Pedra do Frade, com valor de 10,09, que não se destacou em nenhum dos critérios abordados, estando sempre próximo ao valor médio.

Por fim, três dos geossítios atingiram relevância nacional: i) Pedra Furada com a maior pontuação, 16,06, sendo destaque nos Valores de Uso Científico e de Conservação; ii) Praia da Malhada, que apresentou o valor de 13,60; iii) e geossítio Cavernas, com pontuação de 12,47 .

Salienta-se que os geossítios que apresentaram relevância nacional não detiveram relevância internacional por não alcançarem valor suficiente em apenas um campo, sendo ele o "C-03: Presença de Infraestrutura”, já que todos apresentaram valor "zero" enquanto a metodologia requer valor mínimo de "dois". Porém, como foi salientado anteriormente, os geossítios e os demais locais turísticos (com exceção das lagoas do Paraíso, Azul e Torta) no PNJ e adjacências não apresentam infraestrutura para perdurar a ideia de "paraíso natural/preservado" vendida nos pacotes turísticos, sendo o rústico um atrativo e não um elemento de repulsa para o turista. A metodologia base para a etapa da avaliação foi construída para uma realidade distinta da encontrada no PNJ, sendo que o fato ocorrido constitui um problema metodológico, porém como não foi 
objetivo do presente trabalho elaborar uma nova metodologia ou realizar uma adaptação da mesma adotaram-se os valores resultantes.

\section{Considerações finais}

As temáticas da Geodiversidade, do Patrimônio Geológico e da Geoconservação se estruturam enquanto um campo de estudo promissor em meio às Ciências da Terra e na instituição de medidas de preservação ambiental. A Geografia deve se aproximar dessa temática através do incentivo de pesquisas em diferentes estágios (da graduação a pós-graduação), já que o caráter de síntese da ciência geográfica é fundamental na elaboração dos estudos.

A realização de inventários e avaliações quantitativas do patrimônio geológico presente em Unidades de Conservação, como o realizado no presente trabalho, constituem uma estratégia de conservação ambiental e de divulgação dos conceitos referentes às Ciências da Terra, já que um dos objetivos dessas áreas é propagar ações de cunho educativo que resultem na consolidação de consciência ambiental por parte dos visitantes.

O trabalho entra em concordância com pesquisas realizadas por Arruda (2007), Julio (2012) e Julio et al (2013) reafirmando a riqueza da geodiversidade presente no Parque Nacional de Jericoacoara. Porém, ao realizar o inventário e a avaliação quantitativa do patrimônio geológico do PNJ, o trabalho oferece respostas concretas e passíveis de utilização em ações de planejamento ambiental.

Os sete geossítios inventariados no Parque Nacional de Jericoacoara compreendem diferentes categorias temáticas da geodiversidade (eólico, metamórfico, sedimentar, costeiro, entre outros) e apresentam inegável valor cultural, estético, científico e educativo. Todos os geossítios já são utilizados por práticas turísticas o que torna válida a apropriação dos locais por práticas de educação ambiental.

Por meio da avaliação quantitativa dos geossítios, foi possível traçar os locais prioritários na instituição de medidas de valorização. Percebeu-se que os geossítios localizados na Ponta de Jericoacoara se destacaram devido à variedade de elementos da geodiversidade passíveis de abordagem, a relevância cultural-turística e a localização privilegiada nas proximidades da Vila de Jericoacoara.

Espera-se que esse trabalho possa ajudar a difundir a temática da Geodiversidade, Patrimônio Geológico e Geoconservação, especialmente em meio a Ciência Geográfica, incentivando a realização de trabalhos futuros. Por fim, almeja-se também que o mesmo auxilie o Órgão Gestor do Parque Nacional de Jericoacoara em atividades de planejamento territorial e educação ambiental ao elencar os espaços e os temas passíveis de abordagem, sendo, não um fim, mas um meio de promover a difusão do conhecimento geológico e geomorfológico da área. 


\section{Agradecimentos}

Ao Conselho Nacional de Desenvolvimento Científico e Tecnológico pela bolsa de mestrado concedida ao primeiro autor e ao Professor Ricardo Fraga Pereira pela incrível metodologia e ajuda disponibilizada.

\section{Referências}

ARRUDA, M. G. C. Parque Nacional de Jericoacoara: Zoneamento Ambiental para o plano de manejo. Dissertação (Mestrado em Geografia). Universidade Federal do Ceará, Fortaleza, Ceará. 2007.

BORBA, A. W. Geodiversidade e geopatrimônio como bases para estratégias de geoconservação: conceitos, abordagens, métodos de avaliação e aplicabilidade no contexto do Estado do Rio Grande do Sul. Pesquisas em Geociências, n. 38, v. 1, p. 03 13, 2011.

BORBA, A. W.; SOUZA, L. F.; MIZUSAKI, A. M. P.; ALMEIDA, D. P. M.; STUMPF, P. P. Inventário e avaliação quantitativa de geossítios: exemplo de aplicação ao patrimônio geológico do município de Caçapava do Sul (RS, Brasil). Pesquisa em Geociências, v. 40, n. 3, p. 275-294, 2013.

BRILHA, J. Património Geológico e Geoconservação: A Conservação da Natureza na sua Vertente Geológica. Braga: Palimage Editores, 2005.

CARCAVILLA, L.; DURÁN, J. J.; LOPEZ-MARTÍNES, J. Geodiversidade: concepto y relación com el patrimônio geológico. Geo-Temas. Las Palmas de Gran Canaria: v. 10, p. 1299-1303, 2008.

CARVAlho, A. M.; ClaudinO-SAleS, V.; MAIA, L. P.; CAStrO, J. W. A. Eolianitos e de Flecheiras/Mundaú, Costa Noroeste do Estado do Ceará, Brasil - Registro ímpar de um paleosistema eólico costeiro. In: WINGE, M. et al. (Ed.). Sítios geológicos e Paleontológicos do Brasil. Edição 2. Brasília: CPRM, 2009, p. 121 - 130.

CUMBE, A. N. F. O Património Geológico de Moçambique: Proposta de Metodologia de Inventariação, Caracterização e Avaliação. Dissertação (Mestrado em Património Geológico e Geoconservação). Departamento de Ciências da Terra, Universidade do Minho, Braga, Portugal. 2007.

GRAY, M. Geodiversity: valuing and conserving abiotic nature. Londres: John Wiley \& Sons, Ltd. 2004.

GUTIÉRREZ, I. F.; MARTINÉZ, E. F. Geosites Inventory in the Leon Province (Northwestern Spain): A Tool to Introduce Geoheritage into Regional Environmental Management. Geoheritage. v. 2, p. 57-75, 2010.

IRION, G.; MORAIS, J. O.; BUNGENSTOCK, F. Holocene and Pleistocene sea-level indicators at the coast of Jericoacoara, Ceará, NE Brazil. Quaternary Research, v. 77, p. 251-257, 2012. 
JULIO, K. A Ponta de Jericoacoara e seu potencial como sítio geológico no Brasil no patrimônio Mundial (World Heritage Comitte - UNESCO). 109 f. Dissertação (Mestrado em Ciências Marinhas Tropicais). Instituto de Ciências do Mar, Universidade Federal do Ceará, Fortaleza. 2012.

JULIO, K; MAGINI, C.; MAIA, L. P.; CASTRO, J. W. A. Ponta de Jericoacoara, CE Belo promontório de rochas neoproterozóicas associadas a praias e dunas quaternárias com registros de variações do nível do mar. In: WINGE, M. et al. (Ed.). Sítios geológicos e Paleontológicos do Brasil. Volume 3. Brasília: CPRM, 2013, p. 85-94.

LIMA, F. F. Proposta metodológica para a inventariação do patrimônio geológico brasileiro. 91 f. Dissertação (Mestrado em Património Geológico e Geoconservação). Departamento de Ciências da Terra, Universidade do Minho, Braga, Portugal. 2008.

MEIRA, S. A.; MORAIS, J. O. Valores da geodiversidade em geossítios do Parque Nacional de Jericoacoara, Ceará, Brasil. Acta Geográfica, Boa Vista, v. 10, n. 23, p. $1-17,2016$.

MEIRELES, A. J. A; RAVENTOS, J. S. Um modelo geomorfológico integrado para a planície costeira de Jericoacoara/Ceará. Mercator, Fortaleza, n. 1, p. 79 - 94, 2002.

MEIRELES, A. J. A. Geodinâmica dos campos de Dunas Móveis de Jericoacoara. Mercator, Fortaleza, v. 10, n. 22, p. 169-190, 2011.

PEREIRA, P. Património geomorfológico: conceptualização, avaliação e divulgação: Aplicação ao Parque Natural de Montesinho. 370 f. Tese (Doutorado em Ciências). Escola de Ciências, Universidade do Minho, Portugal. 2006

PEREIRA, R. G. F. A. Geoconservação e desenvolvimento sustentável na Chapada Diamantina (Bahia-Brasil). 294 f. Tese (Doutorado em Ciências). Escola de Ciências, Universidade do Minho, Portugal. 2010.

PINTO, A. M. R. T. Caracterização e valorização do património geológico da Penha (Guimarães - Norte de Portugal). 202 f. Dissertação (Mestrado em Património Geológico e Geoconservação). Departamento de Ciências da Terra, Universidade do Minho, Braga, Portugal. 2011.

RIBEIRO, R. R.; CHRISTOFOLETTI, S. R.; BATEZELLI, A.; FITTIPALDI, F. C.; ZANCHETTA, D. Inventário e avaliação do patrimônio natural geológico da região de Rio Claro (SP). Revista do Instituto Geológico, Rio de Janeiro, v. 34, n. 1, 1-21, 2013.

SANTOS, C. A. R. R. Eolianitos de Fernando de Noronha: Processos deposicionais e pós-deposicionais. Dissertação (Mestrado em Geociências). Centro de Tecnologia e Geociências, Universidade Federal de Pernambuco, Recife, 2002.

SIQUEIRA, A. S. A. Geoquímica das lateritas do Domínio Médio Coreaú - Noroeste do estado do Ceará. Dissertação. (Mestrado em Geologia). Departamento de Geologia, Universidade Federal do Ceará, Fortaleza, 2011. 


\section{Suedio Alves Meira}

Bacharel em Geografia pela Universidade Federal do Oeste da Bahia, mestre em Geografia pela Universidade Estadual do Ceará. Atualmente é doutorando no Programa de Pós-Graduação em Geografia da Universidade Federal do Ceará e bolsista Capes.

Universidade Federal do Ceará, Centro de Ciências, Departamento de Geografia.

Av. Humberto Monte, s.n, Campus do Pici, Bloco 911, Fortaleza-CE, CEP: 60.440-554.

Email: suediomeira@gmail.com

JADER ONOFRE DE MORAIS

Geólogo pela Universidade Federal de Pernambuco, Mestre em Marine Earth Sciences e Doutor em Marine Geology pela Universidade de Londres. Professor Titular da Universidade Federal do Ceará e Universidade Estadual do Ceará. Professor permanente nos Programas de Pós-Graduação em Ciências Marinhas Tropicais (UFC) e em Geografia (UECE). Universidade Estadual do Ceará, Centro de Ciências e Tecnologia, Programa de Pós-Graduação em Geografia. Av. Dr. Silas Munguba, 1700, Campus do Itaperi, Fortaleza-CE, CEP: 60.714-903.

Email: jaderonofre@gmail.com

Recebido para publicação em julho de 2016 Aprovado para publicação em janeiro de 2017 